\title{
THE RIGHT TO PAID ANNUAL LEAVE: THE IMPLICATIONS OF ACCESSION
}

\author{
Željko Potočnjak," Andrea Grgić** and Iva Čatipović ${ }^{* * * *}$
}

Summary: The right to paid annual leave is a particularly important principle of EU social law that is regulated by the provisions of Article 7 of the Working Time Directive (WTD), where it enjoys a privileged status as the only non-derogable right. Significantly, Article 7 of the WTD Directive has been interpreted by the Court of Justice of the European Union (CJEU) as a directly effective provision. In Croatian law, this right has been implemented by means of the Labour Act. In this article, we examine three aspects of national regulations regarding paid annual leave against which might raise doubts as to the proper implementation of Article 7 WTD. First, we look at the regulation on minimum periods of employment as a precondition for the entitlement to paid annual leave. Here, we shall argue that the national regulation is not consistent with EU law, as it triggers the accrual of the right to paid annual leave only after half a month of employment. After that, we examine the regulation on the overlap between paid annual leave and other types of leave. We shall claim that national rules regulating overlaps between paid annual leave and maternity, parental, adoption, sick and other paid leave are not in violation of EU law. However, in the case of the overlap between paid leave and unpaid leave stemming from the Maternity and Parental Benefits Act, we raise certain doubts as to the adequacy of national regulations. Our last point of interest is the regulation concerning the carrying-over of untaken paid annual leave into the following calendar year, where we argue that national provisions on the carry-over period are not consistent with Article 7 WTD.

\footnotetext{
Željko Potočnjak, PhD, Professor, Department of Labour and Social Security Law, Faculty of Law, University of Zagreb.

** Andrea Grgić, LLM, Administrator at the Court of Justice of the European Union, PhD candidate, Faculty of Law, University of Zagreb. All opinions expressed herein are personal to the author.

**** Iva Čatipović, LLM, assistant, Department of Labour and Social Security Law, Faculty of Law, University of Zagreb. This article has been written within the ambit of the research project 'Adjustment of Croatian Labour and Social Security Law to the European Social Model' (project leader: Professor Željko Potočnjak, PhD), financed by the Ministry of Science, Education and Sports of the Republic of Croatia.
} 


\section{Introduction}

The right to paid annual leave is one of the cornerstones of labour regulations on working time. Originally linked to the protection of the health and well-being of workers to help them to be more productive,$^{1}$ this right was recognised for the first time at the international level in the 1936 International Labour Organization (ILO) Holidays with Pay Convention, ${ }^{2}$ and is now included in all major international human rights documents, ${ }^{3}$ as well as being enshrined in the national legislation of all Member States of the EU. Concomitantly, its pivotal nature has been acknowledged by European Union (EU) law. With its formal legal basis in the health and safety provisions of the Treaty on the Functioning of the European Union (TFEU), ${ }^{4}$ the right to paid annual leave is regulated by Article 7 of the Working Time Directive 2003/88 (WTD), which provides entitlement to a minimum of four weeks of paid annual leave ${ }^{6}$ for every worker in all sectors of activity, public or private. ${ }^{7}$ This minimum period may only be replaced by payment in lieu when the employment relationship is terminated. Importantly, this right enjoys a privileged status as the only non-derogable right regulated by the WTD. In addition, the right to paid annual leave is mentioned in the Community Charter of the Fundamental Social Rights of Workers ${ }^{8}$ and in the Charter of Fundamental Rights of the EU, ${ }^{9}$ and is recognised as a right on its own by both documents, the latter linking it to the notion of solidarity. According to the Court of Justice of the EU (CJEU or Court), the right to paid annual

\footnotetext{
1 ILO, 'Working Time in the Twenty-first Century' (Report for discussion at the Tripartite Meeting of Experts on Working Time Arrangements, Geneva, 17-21 October 2011) 15.

2 Convention no 52 concerning Annual Holidays with Pay (adopted 24 June 1936, entered into force 22 September 1939), revised by Convention no 132 concerning Annual Holidays with Pay (adopted 24 June 1970, entered into force 30 June 1973).

3 Universal Declaration of Human Rights (adopted 10 December 1948 UNGA Res 217 A(III) (UDHR) art 24; International Covenant on Economic, Social and Cultural Rights (adopted 16 December 1966, entered into force 3 January 1976) (ICESCR), art 7(d); European Social Charter 1961, art 2, point 3; European Social Charter 1996 (revised), art 2, point 3.

4 Consolidated version of the Treaty on the Functioning of the European Union [2010] OJ C 83/01, art 153. At the time of the adoption of the WTD, art 153 TFEU was EC Treaty (Treaty of Rome, as amended) art 137.

5 Directive 2003/88/EC of the European Parliament and of the Council of 4 November 2003 concerning certain aspects of the organisation of working time [2003] OJ L229/9.

6 Member States are allowed to provide for a paid annual leave of longer duration. See, for example, Case C-342/01 Merino Gómez [2004] ECR I-02605, para 43. They are also allowed to provide for the entitlement to paid annual leave under national law to vary according to the reason for a worker's absence on health grounds, provided that the entitlement is always equal to or exceeds the minimum period of four weeks of paid annual leave. See Case C-282/10 Dominguez [2012] ECR I-000, para 49.

7 WTD, art 1(3).

8 Community Charter of the Fundamental Social Rights of Workers, European File 6/90, May 1992, art 8.

9 Charter of Fundamental Rights of the European Union [2010] OJ 83/02, art 31.
} 
leave is 'a particularly important principle of [EU] social law ... whose implementations by the competent national authorities must be confined within the limits expressly laid down'10 by the WTD.

Despite its recognition as a fundamental social right, the effect of EU law provisions on paid annual leave is to an extent limited from the perspective of the individual worker if he/she is precluded from exercising the Article 7 WTD right to paid annual leave due to a conflicting provision of national law. Namely, in the case of a conflicting provision of national law, the effect of Article 7 WTD on individual employment relationships depends on the type of employer. In vertical situations, when the employer is a state body, a national judge has to set aside the conflicting provision of national law, applying directly Article 7(1) WTD to the individual employment relationship. ${ }^{11}$ Accordingly, a worker is able to rely on it directly, since Article 7(1) WTD fulfils the conditions to produce direct effect. ${ }^{12}$ In horizontal situations between private parties, however, the effect of Article 7(1) WTD is qualified. As the directives are not capable of producing horizontal direct effect, individual workers cannot directly invoke Article $7(1)$ WTD against an employer who is a private entity. ${ }^{13}$ In this case, a national judge has the duty to apply and interpret national law, as far as possible, in the light of the wording and purpose of Article 7 WTD in order to achieve the result pursued by the latter. ${ }^{14}$ If such an interpretation is not possible, the individual worker is effectively precluded from claiming the right to (paid annual) leave and can only obtain compensation for the loss sustained. ${ }^{15}$

The described discrepancy caused by the lack of horizontal direct effect of directives demonstrates that the provisions of EU law cannot unequivocally substitute conflicting national provisions on paid annual leave. This, in turn, puts an additional emphasis on the implementation of Article 7 WTD in national law. Therefore, in this paper we will examine the Croatian legislation on paid annual leave against the background of EU law. Three aspects of national legislation which might raise doubts as to the proper implementation of Article 7 WTD in Croatian law will be examined. Our first point of interest will be the regulation on minimum periods of employment as a precondition for the entitlement to paid

10 Case C-173/99 BECTU [2001] ECR I-4881, para 43.

11 Dominguez (n 6) paras 38-39, 41.

12 Dominguez (n 6) para 34.

13 Dominguez (n 6) para 42.

14 Dominguez (n 6) paras 24-25, 27. The application and interpretation of national law is limited by general principles of law and cannot serve as a basis for an interpretation of national law contra legem. See Dominguez (n 6) para 27.

15 Dominguez (n 6) para 43. 
annual leave. We will look at whether Article 59(2) of the Labour Act, ${ }^{16}$ which regulates the calculation of the proportional time of paid annual leave, contravenes Article 7 WTD to the extent that it triggers the accrual of the right to paid annual leave only after half a month of employment. In the section that follows, we will examine the relationship between paid annual leave and other periods of leave. We will start by focusing on the overlap between paid annual leave, sick leave and maternity leave respectively, as these have been examined by the CJEU. After that, we will examine whether the principle that paid annual leave should not overlap with sick leave and maternity leave can be applicable to other types of leave recognised by national law but not yet challenged before the CJEU. The last section will be devoted to the carrying-over of untaken paid annual leave into the following calendar year. Here, we will look into the national provisions on the carry-over period, raising the issue of its length. In our concluding remarks, we will suggest how Croatian law can be brought into conformity with EU law.

\section{Minimum period of employment as a precondition for entitlement to paid annual leave}

\subsection{The EU law perspective}

The question of whether conditioning the right to paid annual leave to a certain period of uninterrupted employment is in accordance with Article 7 WTD was put forward for the first time in the $B E C T U^{17}$ case. Under the relevant UK legislation, the entitlement to paid annual leave did not arise until a worker was continuously employed for 13 weeks with the same employer. Since most of BECTU's members were on short-term contracts, many of them did not satisfy this condition. Accordingly, they were deprived of any entitlement to paid annual leave and of any right to allowance in lieu merely because, although they worked on a regular basis, they did so for successive employers. ${ }^{18}$ The CJEU made a distinction between 'the entitlement of every worker to paid annual leave' as a 'particularly important principle of [EU] social law from which there can be no derogation and whose implementation by the competent national authorities must be confined within the limits expressly laid down'19 by the WTD and the conditions of exercising that right. Although, the WTD left the regulation of the conditions for entitlement and the granting of the entitlement to paid annual leave to the Member States, the CJEU stated

16 Zakon o radu (Labour Act), Narodne novine (Official Gazette), 149/09, 61/11, 82/12, $73 / 13$.

$17 B E C T U$ (n 10).

$18 B E C T U$ (n 10) para 27.

19 BECTU (n 10) para 43. 
that this regulation must be 'construed as referring only to the arrangements $^{20}$ for paid annual leave adopted in the various Member States'. ${ }^{21}$ Consequently, the Member States are not allowed to 'adopt national rules under which a worker does not begin to accrue rights to paid annual leave until [he/she] has completed a minimum period' of employment, ${ }^{22}$ and so the contested UK legislation was not compatible with the WTD.

This basic idea that the accrual of the right to paid annual leave cannot be conditioned by a minimum period of employment was further developed in the Schultz-Hoff and Stringer ${ }^{23}$ and Dominguez ${ }^{24}$ cases. Both cases will be amply examined in the sections which follow. Here, it is sufficient to say that in the first case the appellants in the main proceedings were unable to take paid annual leave within a certain period of time provided by national legislation because they were on sick leave. In the second case, national legislation made the entitlement to paid annual leave conditional on a minimum of ten days' (or one month's) actual work during the reference period. Consequently, Ms Dominguez was refused her right to paid annual leave because she was on sick leave the whole reference year. In Schultz-Hoff and Stringer, the Court stated that the WTD, in relation to paid annual leave, does not distinguish between workers on sick leave and those who actually worked in the course of that year. As both groups of workers are covered by the WTD, the CJEU concluded that Member States cannot condition the right to paid annual leave by the obligation to have actually worked during the course of the year in which the leave had to be taken. In Schultz-Hoff and Stringer, the applicant was not able to take the already accrued paid annual leave because he was on sick leave, ie a period of time in which he did not perform any actual work. The Dominguez case was more straightforward, because the applicant was prevented from accruing paid annual leave. In other words, she did not have any entitlement to it. Here the Court, combining BECTU and Schultz-Hoff and Stringer, went one step further by saying that Article 7(1) WTD must be interpreted as 'precluding national provisions or practices which make entitlement to paid annual leave conditional on a minimum period of ten days' or one month's actual work during the reference period'. ${ }^{25}$

\footnotetext{
20 According to Ricci, those would be, for example 'planning of the periods, the worker's obligation to give advance notice to the employer of the intended leave period, the possibility to require a minimum period of work before leave can be taken, criteria for proportionate calculation of annual leave in cases where the relationships lasts less than one year'. G Ricci, 'BECTU: An Unlimited Right to Annual Paid Leave' [2001] 30(4) Industrial Law Journal 401, 405.

21 BECTU (n 10) para 53.

$22 B E C T U$ (n 10) para 53.

${ }^{23}$ Cases C-350/06 and C-520/06 Schultz-Hoff and Stringer [2009] ECR I-179.

24 Dominguez (n 6).

25 Dominguez (n 6) para 21.
} 
A discussion on the accrual of paid annual leave would not be complete without mentioning cases which seem to open the possibility of justifying the provisions of national law which condition the entitlement of the right to paid annual leave to a certain period of employment or actual work. The CJEU seemed to find justification in other EU legislation. In the Tirols ${ }^{26}$ case, it invoked the Framework Agreement on Fixed Term Work, ${ }^{27}$ which is based on the principle of non-discrimination between fixed-term and permanent workers, and which at the same time allows for the principle of pro rata temporis to be applicable, when appropriate. ${ }^{28}$ According to the latter principle, it is possible to differently calculate the rights of fixed-term workers by reference to the duration of their contract, provided that this is done on objective grounds. In Tirols, however, the CJEU found that a provision of Austrian law which excluded workers working less than a maximum of six months or on a casual basis from accruing the right to paid annual leave could not be kept, as it was not justified on objective grounds. The justification given by the Austrian Government, namely that the contested provision served as a stimulation for employment, did not respond to a genuine need, and was not appropriate for achieving the objective pursued or necessary for that purpose. It was a mere budgetary consideration which could thus not justify discrimination. $^{29}$

A similar reasoning was invoked in Heimann and Toltschin, ${ }^{30}$ albeit with reference to the Framework Agreement on Part-Time Work ${ }^{31}$ and with a different outcome. In this case, the CJEU examined a provision of a social plan agreed between an employer and a works council which enabled the extension of employment contracts for dismissed workers by 'zero-hours short time working'. Under this arrangement, the dismissed workers had the opportunity of receiving, in the year following their dismissal, a financial allowance from the state. However, as all the rights and obligations from the employment relationship were suspended, the applicants did not acquire any rights to paid annual leave for that year. Even though the arrangement was considered, from a formal point of view, a full-time employment contract of a limited duration, due to the zero-time work the CJEU regarded the workers as 'temporary part-time workers'. As the workers were suspended from working under an arrangement which gave them time to rest and resort to leisure activities,

\footnotetext{
26 Case C-486/08 Tirols [2010] ECR I-03527.

27 Council Directive 1999/70/EC of 28 June 1999 concerning the framework agreement on fixed term work concluded by ETUC, UNICE and CEEP [1999] OJ L175/43.

28 Council Directive 1999/70/EC (n 27) clause 4.

29 Tirols (n 26) paras 44-46.

30 Cases C-229/11 and C-230/11 Heimann and Toltschin [2012] ECR I-000.

31 Council Directive 97/81/EC of 15 December 1997 concerning the framework agreement on part-time work concluded by UNICE, CEEP and the ETUC [1998] OJ L14/9.
} 
and given that the purpose of the arrangement worked for the financial benefit of the workers, the CJEU found the social plan to be a proper application of the pro rata temporis principle and not in violation of the principle of non-discrimination of part-time and full-time workers envisaged by the Framework Agreement on Part-Time Work. Consequently, the CJEU did not find the social plan incompatible with Article 7 WTD.

To sum up, following the CJEU ruling in BECTU, it is necessary to distinguish between the entitlement to paid annual leave, which cannot be negated by reference to national legislation and/or practice, and conditions of exercising that right, which can be determined by national law and/or practice. Entitlement to paid annual leave cannot be conditioned by either minimum periods of employment (BECTU) or a minimum period of actual work during the reference period (Dominguez). However, after Tirols and Heimann and Toltschin, it is clear that in contracts of limited duration the CJEU allows for the concomitant application of the principle of pro rata temporis. The question to which we now turn is whether the Croatian rules on the accrual of the right to paid annual leave are in line with this jurisprudence. We shall start by introducing the relevant national provisions on paid annual leave.

\subsection{The Croatian law perspective}

Whilst the right to paid annual leave is enshrined in the Croatian Constitution, ${ }^{32}$ Article 7 of the WTD is implemented by Heading VII of the LA (Rests and Leaves), which applies to all sectors of economic activity as a general act, entitling every worker to a minimum period of four weeks of leave per reference period of one calendar year. ${ }^{33}$ A longer duration of leave is granted to certain protected groups of workers, ${ }^{34}$ and the LA gives workers and employers the opportunity to bargain individually and collectively on this matter, provided that the statutory minimum is respected. ${ }^{35}$ During his/her annual leave, a worker has to be given compensation which cannot be lower than the amount of the average salary that has been paid to him/her within the three months prior to the leave. ${ }^{36}$ An agreement on payment in lieu is null and void as well as any waiver of right to paid annual leave. ${ }^{37}$ In practice, four weeks of paid an-

\footnotetext{
32 Ustav Republike Hrvatske (Constitution of the Republic of Croatia), Narodne Novine (Official Gazette), 56/1990, 135/1997, 8/1998, consolidated text, 113/2000, 124/2000; 28/2001, 41/2001; 55/01; correction, 76/10 and 85/10.

33 LA (n 16) art 55(1).

34 LA (n 16) art 55 (2) provides for a minimum of five weeks of paid annual leave to minor workers and workers who are subject to influences harmful for their health at work.

35 LA (n 16) art 56 (1).

36 LA (n 16) art 60(1).

37 LA (n 16) art 57.
} 
nual leave are expressed in days, and so the exact number of days of paid annual leave depends on the organisation of the working week of a particular employer. ${ }^{38}$ Here, the rules on weekly rest play a role, as the days of weekly rest are exempted from the calculation of the number of days of annual holiday together with public holidays, statutory granted free days, ${ }^{39}$ and other types of leave (such as sick leave ${ }^{40}$ or maternity and parental leave), ${ }^{41}$ which are to be exercised in their own right. Therefore, for example, a worker who works five days a week and has two days of weekly rest is guaranteed twenty days of paid annual leave, whereas a worker who works six days a week (and has only one day of weekly rest, which is the statutory minimum) is guaranteed twenty-four days of annual holiday.

Special rules are provided for the accrual of the right to paid annual leave. Article 58(1) LA stipulates that a worker who is employed for the first time and a worker who has a gap between two consecutive employments longer than eight days acquire the right to annual leave after six months of a continuous employment relationship. ${ }^{42}$ However, a worker who does not meet these conditions is not left without leave during the first six months of work, since Article 58 LA should be read in conjunction with 59 LA which provides for a proportional period of paid annual leave. The latter article differentiates between four situations in which a worker meets the envisaged six-month period of continuous employment, three of those being of immediate interest to us. The first situation arises when a worker does not accrue six months of an employment relationship in the calendar year in which the employment started but who continues to be employed in the following calendar year..$^{43}$ The second one occurs when the employment relationship terminates before the six-month period in a given calendar year, ${ }^{44}$ and the third one deals with situations of termination of employment relationships before 1 July of a given calendar year. ${ }^{45}$ The aforementioned situations are complemented

\footnotetext{
38 Opinion of the Ministry of Labour and Pension Systems, KLASA: 110-01/12-01/42, URBROJ: 524-08-01-01/5-12-2, of 13 February 2011 <http://www.mrms.hr/topics/zakon-o$\mathrm{radu} / \mathrm{page} / 21 />$ accessed 28 June 2014.

39 LA (n 16) art 56(2).

40 LA (n 16) art 56(3).

${ }^{41}$ LA (n 16) art 63(3).

42 According to Article 56(2) LA '[t]emporary inability to work, performing citizen duties in defence service or other situation of justifiable absence from work determined by law are not considered as interruption of work within the meaning of paragraph 1 of this Article.'

43 LA (n 16) art 59(1)(1).

44 LA (n 16) art 59(1)(2).

45 LA (n 16) art 59(1)(3). The fourth situation refers to workers who in a calendar year are employed by two or more employers on a part-time basis, and stipulates that the paid annual leave with all these employers cannot exceed the statutory minimum of four weeks of paid annual leave. See LA, art 59(1)(4).
} 
by the rules on the calculation of proportional time. The mathematical formula for the calculation of the proportional time of paid annual leave can be expressed in the following terms:

\section{$X / 12 \times(W D P W \times 4)=$ Rounded days of paid annual leave}

As a starting point, a worker has the right to one-twelfth of the prescribed annual leave for each calendar month of work. ${ }^{46}$ Here, at least half of a month of work is rounded up to a whole month of work. Therefore, ' $\mathrm{X}$ ' signifies the number of months of work of a particular worker. The figure gained by division in the equation is then multiplied by working days per week (WDPW) with the particular employer, and again multiplied by 4 (the number of weeks of paid annual leave). However, the figure obtained by the last two mathematical operations does not necessarily give the exact number of days of paid annual leave. This is because, according to the LA, at least half a day of annual leave is rounded up to a whole day of leave. ${ }^{47}$ To demonstrate how these rules operate, let us use a simple example: the agreed duration of employment was from 1 July to 18 August on the basis of four working days per week. Even though the agreed period encompasses one month and 18 days, following the rules on calculation of accrual, it has to be considered that he/she was employed for two months. It also has to be considered that he/she accrued three days of paid annual leave, even though the rules of mathematics indicate that he/she in fact accrued 2.667 days of leave. ${ }^{48}$

The problem with the calculation of the proportionate amount of annual leave lies in the aforementioned Article 59(2) LA. According to this, 'at least one half of a month of work is rounded up to a whole month [of work]'. On the positive side, it is clear that this provision grants the right to paid annual leave equal to one month of work to a worker who was engaged in employment for less than a month, provided that the employment relationship lasted at least half of a month. On the negative side, due to this provision, any work shorter than a half of a month in not taken into consideration for the purpose of calculating annual leave. This negative repercussion may arise in three situations. The first two are not so straightforward, as they cover situations in which the employment relationship lasts for more than half a month (but less than six months). In the first one, the employment relationship ends in the first half of a

\footnotetext{
46 For a more in-depth explanation of the rules on the calculation of proportional time of paid annual leave, see V Ivanko, 'Rok za stjecanje prava na godišnji odmor, pravo na razmjeni dio godišnjeg odmora, pravo na godišnji odmor kod promjene poslodavca' [2013] Radno pravo $7-8,32$.

47 LA (n 16) art 59(2).

48 Namely, $2 / 12 \times(4 \times 4)=2.667$.
} 
month. This would be the case if the employment relationship starts on 1 July and ends on 11 August. In the second one, the employment relationship starts in the second half of a month. This would occur if the employment relationship starts on 27 July and ends on 1 September. In these two situations, work performed over periods of time shorter than half a month is exempted from the calculation of the proportionate time of annual leave. In other words, during these periods, the worker does not accrue any annual leave, although he/she actually worked. The third situation is more straightforward, as it arises when the employment relationship lasts, in total, for less than half a month, for example for 10 days. Here, the worker is completely deprived of any paid annual leave and consequently any allowance in lieu.

In our opinion, the described negative repercussions of Article 59(2) LA make this provision of the LA highly contestable from the position of EU law. Namely, we find it in conflict with the CJEU's ruling in the $B E C T U$ case, for it is, albeit construed as a condition of exercising the right to paid annual leave, in essence a precondition for entitlement to paid annual leave. This is most evident in situations when the beginning of an employment relationship falls in the second half of a month, and when the total duration of an employment relationship does not meet the condition of half a month of work. Although the CJEU has never ruled on a situation when the accrual of paid annual leave is suspended before the end of the employment relationship, ${ }^{49}$ we find the principle expressed in BECTU of equal relevance simply because the worker is not entitled to leave for the period of time in which she or he actually worked, without having any reduction in their working time. The discrepancy between Article 59(2) and EU law becomes even more striking when we refer to the Dominguez case in which the CJEU stated that the entitlement to paid annual leave cannot be conditioned even by periods of minimum actual work. Furthermore, from the perspective of the BECTU and Dominguez cases, we see no difference between whether the entitlement to paid annual leave is suspended from accrual at the beginning or at the end of the employment relationship, or for the whole duration of it. What we find important here is that those workers who are in a weaker bargaining position with regard to the calendar date on which the employment relationship starts or ends are deprived of accruing the right to paid annual leave without any objective justification. To that end, it is necessary to emphasise that the three described situations which might result from the application of Article 59(2) to the workers' detriment need to be differentiated from the Heimann and Toltchin case for two reasons. First, in the aforementioned case, the workers' duty to work was completely or

49 In Heimann and Toltschin (n 30), the non-accrual of the right to paid annual leave started after the end of the employment relationship. 
partially suspended. In Croatian law, as already mentioned, it is quite the opposite. Second, in Heimann and Toltchin, there was a direct link between the suspension from work and the benefit for the workers, as the German Federal Employment Agency envisaged a special unemployment benefit (Kurzabeitgeld) for those working on 'zero hours-short time working'. In Croatian law, as it now stands, periods of time shorter than half a month are not per se taken into account for the purposes of unemployment benefit. Even though they are taken into consideration for the purpose of qualification for unemployment benefit, ${ }^{50}$ whether or not they will actually lead to unemployment benefit is a matter of the personal work history of an individual worker and not an issue of a co-ordinated state policy. Therefore, as in the Tirols case, it is difficult to see any objective justification for the provision of Article 59(2) LA.

\section{The relationship between paid annual leave and other periods of leave}

\subsection{The EU law perspective}

Probably the most litigated aspect of the right to paid annual leave is that concerning the relationship between this kind of leave and other periods of leave. This arises in situations when annual leave, usually fixed in advance by a statute, collective agreement or employer's unilateral decision, coincides with a period of another leave, and has three strands. The first one poses the question whether the right to paid annual leave accrues during other periods of leave. In the last section, we saw that the CJEU answered this question in the affirmative with regard to sick leave, stating that the right to paid annual leave conferred by the WTD cannot be made subject to a condition to have actually worked during the reference period laid down by a Member State. ${ }^{51}$ The second strand raises the issue whether other periods of leave consume acquired but untaken paid annual leave, while the third one, which will be discussed more closely in the following section, concerns the question of the existence and length of the carry-over period of untaken paid annual leave. While the text of the WTD is silent on these three issues, the CJEU has been quite resolute in defending the right to take annual leave.

The protection of workers who are unable to take paid annual leave in the reference period started with the securing of this right when annual leave coincides with other leave recognised by EU law. The issue

\footnotetext{
50 According to the Act on Employment Intermediation and Rights in the Case of Unemployment, a person qualifying for unemployment benefit has to be employed for at least nine inconsecutive months in a period of twenty-four consecutive months, Act on Employment Intermediation and Rights in the Case of Unemployment 2008, art 37(1).

51 Schultz-Hoff and Stringer (n 23) paras 40-41; Dominguez (n 6) para 20.
} 
of overlap was raised for the first time in the Merino Gómez ${ }^{52}$ case with regard to maternity leave granted by the Pregnant Workers Directive. ${ }^{53}$ Ms Merino Gómez was a factory worker whose maternity leave coincided with the period of acquired annual leave pre-fixed by a collective agreement. Consequently, she was denied the right to take paid annual leave at a later date. For the CJEU, it was crucial to examine the purpose of the entitlement to annual leave. The Court concluded that it:

is different from that of the entitlement to maternity leave. Maternity leave is intended, first, to protect a woman's biological condition during and after pregnancy and, second, to protect the special relationship between a woman and her child over the period which follows pregnancy and childbirth. ${ }^{54}$

In the light of this, the CJEU distinguished between annual leave and maternity leave, and concluded that in such circumstances 'a worker must be able to take her annual leave during a period other than the period of her maternity leave', ${ }^{55}$ This conclusion was bolstered by the Sex Equality Directive, ${ }^{56}$ which required equal treatment of men and women with regard to working conditions. Therefore, women could not be subjected to unfavourable treatment regarding the right to take annual leave because of pregnancy or maternity.

While the recognition of the right to take annual leave separately from maternity leave did not raise much controversy, ${ }^{57}$ probably because it tackled the issue of sex equality, the jurisprudence which followed demonstrated that the CJEU is ready to give full effect to the right to annual leave even when it coincides with a period of leave which is not recognised by EU law. The joint Schultz-Hoff and Stringer cases were

\footnotetext{
52 Merino Gómez (n 6).

53 Council Directive 92/85/EEC of 19 October 1992 on the introduction of measures to encourage improvements in the safety and health at work of pregnant workers and workers who have recently given birth or are breastfeeding (tenth individual Directive within the meaning of Article 16(1) of Directive 89/391/EEC) [1992] OJ L348/1.

54 Merino Gómez (n 6) para 32.

55 Merino Gómez (n 6) para 37.

56 Council Directive 76/207/EEC of 9 February 1976 on the implementation of the principle of equal treatment for men and women as regards access to employment, vocational training and promotion, and working conditions [1976] OJ L39/40. Now replaced by Directive 2006/54/EC of the European Parliament and of the Council of 5 July 2006 on the implementation of the principle of equal opportunities and equal treatment of men and women in matters of employment and occupation (recast) [2006] OJ L204/23.

57 Merino Gómez (n 6) was a Chamber case. Only two Member States submitted written observations (Spain and Italy), both in favour of Ms Merino Gómez (see Case C-342/01 Merino Gómez [2004] ECR I-02605, Opinion of AG Mischo, paras 27-28).
} 
ground-breaking in this respect. ${ }^{58}$ In Schultz-Hoff, the applicant was on long-term sick leave due to which he was unable to take annual leave. Upon retirement related to his incapacity to work, he demanded payment in lieu for the 2 years in which he was on sick leave. Stringer concerned two categories of applicants. The first, similar to Mr Schultz-Hoff, were on long-term sick leave before the termination of their contracts, and demanded payment in lieu, while the second involved a worker who was on sick leave of indefinite duration and who wished to take a number of days of paid annual leave for a certain period following her request. In both the Schultz-Hoff and Stringer cases, the applicants were refused on the grounds of national laws which required that the annual leave be taken in the year to which it referred or in the carry-over period following that year. As in the Merino Gómez case, the CJEU distinguished the purposes of the two kinds of leave in question, and found that while:

it is common ground that the purpose of the entitlement to paid annual leave is to enable the worker to rest and to enjoy a period of relaxation and leisure[, $t$ ]he purpose of the entitlement to sick leave is different. It is given to the worker so that he can recover from being ill. ${ }^{59}$

The CJEU, however, also contrasted maternity and sick leave, since the latter right is not governed by EU law. ${ }^{60}$ Nonetheless, the CJEU recalled the aforementioned BECTU judgment, reiterating that, although it is for the Member States to lay down the conditions for the exercise and implementation of the right to paid annual leave, they are not allowed to make the very existence of that right subject to any preconditions whatsoever. Consequently, the CJEU concluded that Article 7(1) WTD does not preclude national legislation or practice from either allowing ${ }^{61}$ or pre-

\footnotetext{
58 Schultz-Hoff and Stringer (n 23) was a Grand Chamber case. Written observations were submitted by eight Member States (Germany, the United Kingdom, Belgium, the Czech Republic, Italy, the Netherlands, Poland and Slovenia).

59 Schultz-Hoff and Stringer (n 23) para 25.

60 Schultz-Hoff and Stringer (n 23) para 27. Although Bogg is of the view that maternity leave should in this context be treated differently from sick leave, he also notes that it is a fair criticism of the Court of Justice in Stringer that it never explains why this difference should be legally consequential'. He explains that demarcation of Community-guaranteed periods of leave, regardless of worker or employer preferences, ensures the integrity of important collective goods such as a public culture respective of gender equality and equal parenting'. What makes the interrelationship between annual leave and sick leave (as a period of leave granted only by national law) different is that permitting workers to 'designate a period of sick leave as annual leave is facilitative of worker autonomy without undermining the public culture of respect for gender equality and equal parenting'. A Bogg, 'Of Holidays, Work and Humanisation: A Missed Opportunity?' [2009] 34 EL Rev 738, 742, 745.

61 Schultz-Hoff and Stringer (n 23) para 31.
} 
cluding ${ }^{62}$ a worker on sick leave from taking paid annual leave during that leave, providing that the worker has the opportunity to exercise the right to paid annual leave during another period. ${ }^{63}$ Regarding the question of the extinction of the right to annual leave due to the termination of the employment contract, the CJEU finally stated that neither the right to paid annual leave nor the right to payment in lieu is lost due to the termination of the employment relationship when the worker's incapacity to work, which was the reason why he could not exercise his right to annual leave in the first place, continues after that date.

Subsequent CJEU judgments dealt with other aspects of the right to paid annual leave, such as the issue of a worker becoming unfit for work before the date of his allocated annual leave ${ }^{64}$ and becoming unfit for work during a period of paid annual leave. ${ }^{65}$ In both situations, the CJEU concluded that a worker has to subsequently be entitled to the untaken annual leave. Regarding the scheduling of the new period of leave, the CJEU observed that it is subject to the rules and procedures of national law applicable to the scheduling of workers' leave, and should take into account the various interests involved, including overriding reasons relating to the interests of the undertaking. If such interests preclude acceptance of the worker's request:

the employer is obliged to grant the worker a different period of annual leave proposed by him which is compatible with those interests, without excluding in advance the possibility that that period may fall outside the reference period for the annual leave in question. ${ }^{66}$

Summing up the CJEU case law on overlaps, it cannot be inferred that either maternity or sick leave can be used as an obstacle to the exercise of the right to paid annual leave. This does not mean that one leave should prevail over the other. It simply means that the Member States

\footnotetext{
62 Schultz-Hoff and Stringer (n 23) para 29.

63 Bogg thinks that there are three possible answers to the question of exercising the entitlement to annual leave during a period of sick leave: I) the 'prohibitive' model (AG Trstenjak's approach), requiring Member States to exercise annual leave during sick leave; II) the 'permissive' model (the CJEU's approach), allowing Member States to choose either to permit or to prohibit the exercise of annual leave during sick leave; III) the 'facilitative' model, the 'humanisation of work' approach (upheld by the author), requiring Member States to permit annual leave to be exercised during sick leave. He believes workers' autonomy is only protected sufficiently by the 'facilitative' model: it should be the workers' choice to designate (or not to designate) a period of sick leave as annual leave. Bogg (n 60) 740-745.

64 Case C-277/08 Pereda [2009] ECR I-08405; Case C-194/12 Maestre García [2013] ECR I-000.

65 Case C-78/11 ANGED [2012] ECR I-000.

66 See also Pereda (n 64) para 23; Maestre Garcia (n 64) para 23.
} 
should take all necessary measures to accommodate paid annual leave with maternity and sick leave.

So far, we have focused on the way the CJEU has addressed the issue of overlap between paid annual leave and other periods of leave. We will now turn to provisions of Croatian law regulating this matter. We start by considering the rules on overlap between paid annual leave and sick, maternity, parental and adoption leave, respectively. Following this, we question the regulation of the overlap between paid annual leave and other types of paid and unpaid leave recognised by Croatian law.

\subsection{The Croatian law perspective}

\subsubsection{Maternity, parental and adoption leave}

The LA contains only very broad stipulations regarding periods which should not interfere with the duration of paid annual leave, providing in Article 56 that 'bank holidays and non-working days established by law are not included in the duration of annual leave'67 as well as 'a period of temporary inability to work, which was confirmed by an authorized physician'. ${ }^{68}$ While it is clear that the latter formulation refers to sick leave, it is not quite clear whether the formulation 'non-working days established by law' encompasses maternity leave, parental and adoption leave. ${ }^{69}$ Both jurisprudence and doctrine are silent on this issue. Be that as it may, it seems that this vagueness of the statutory provision does not pose a serious problem in practice. This is probably because these three types of leave are explicitly mentioned in Article 63(3) LA, which provides for more favourable regulation of carrying over untaken or interrupted annual leave to the following calendar year for workers who have been unable to take it due to 'illness or maternity, parental or adoption leave.' We are of the opinion that this provision makes it clear that maternity, parental or adoption leave interrupt annual leave, and that a worker shall be granted the right to paid annual leave after the maternity, parental or adoption leave has expired. ${ }^{70}$ Besides this, in practice Article 63(3) LA has been interpreted in a way that the right to paid annual leave does not stop accruing during sick, maternity, parental or adoption leave. ${ }^{71}$

\footnotetext{
67 LA, art 56(2).

68 LA, art 56(3).

69 Entitlement to and duration of maternity, parental and adoption leave is regulated by the Maternity and Parental Benefits Act 2008.

70 We would like to thank Ivana Grgurev for drawing our attention to this provision.

71 Opinion of the Ministry of Labour and Pension Systems, KLASA: 110-01/12-01/161, URBROJ: 524-08-01-01/5-12-2, of 12 April 2012 and KLASA: 110-01/12-01/161, URBROJ: 524-08-01-01/5-12-4, of 5 June 2012 <http://www.mrms.hr/topics/zakon-o$\mathrm{radu} / \mathrm{page} / 20 />$ accessed 28 June 2014 .
} 
Therefore, we find this provision to be in compliance with Article 7 WTD. Nonetheless, at this point we would like to address a concern that has been raised in relation to the potential ramifications of the SchultzHoff and Stringer judgment, which established the rule that the right of workers on sick leave to take annual leave cannot be extinguished at the end of the carry-over period. Although acknowledging that this rule favours workers, some commentators have raised doubts that this rule could lead to the termination of the employment of sick workers by employers in order to avoid the financial and practical ramifications of long periods of accrued annual leave. ${ }^{72}$ We believe that under Croatian law, there is no place for such a concern for a number of reasons. First, the LA expressly prohibits the dismissal of workers on sick leave when a temporary inability to work is caused by an injury at work or an occupational disease. ${ }^{73}$ Such workers can only be dismissed upon their return to work, following a procedure which offers a number of safeguards in favour of the worker. ${ }^{74}$ Second, even though the LA does not prohibit the dismissal of workers on sick leave which is not related to injury at work or an occupational disease, it expressly states that that leave on the grounds of disease or injury cannot be a reason for dismissal. ${ }^{75}$ Third, in the case of dismissal, the burden of proof is on the employer, who has to prove that the dismissal was legally justified. ${ }^{76}$ Fourth, the LA stipulates that in the case of dismissal, the notice period does not run during sick leave, irrespective of the reasons which led to the temporary inability to work. ${ }^{77}$ Needless to say, the right to paid annual leave does not stop accruing during the dismissal period even though the worker is on sick leave. ${ }^{78}$ Finally, the provisions of the LA are additionally bolstered by the provisions of the Anti-discrimination Act, which prohibits discrimination on the grounds of both disability and health status in relation to working conditions, which includes dismissal. ${ }^{79}$

\footnotetext{
72 See R Capper, 'The Right to Have Holiday Pay whilst off Sick' [2009] 30(6) Business Law Review 134; C Barnard, EU Employment Law (4 ${ }^{\text {th }}$ edn, OUP 2012), 546.

73 LA, art 74(1).

74 LA, arts 78-79, 107. Safeguards include, for example, the duty to prequalify the worker for work which suits his/her health condition or to offer better suited work. In addition, in general, it is not possible to dismiss this type of worker without the approval of a works council or trade union representative.

75 LA, art 109(1).

76 LA, art 131.

77 LA, art 113(2).

78 Opinion of the Ministry of Labour and Pension Systems of 25 January $2010<\mathrm{http}: / /$ www.mrms.hr/topics/zakon-o-radu/page/21/> accessed 28 June 2014.

79 Zakon o suzbijanju diskriminacije (Anti-discrimination Act), Narodne novine (Official Gazette), 85/08, 112/12) arts 1(1), 8(1)(1).
} 
3.2.3 Other leave recognised by Croatian law and its conflict with the right to paid annual leave

So far, the CJEU has dealt only with the conflict between the right to paid annual leave and maternity leave (as a period of leave granted by EU law) and sick leave (as a period of leave not granted by EU law). The Croatian legal system knows many other types of paid and unpaid leave which fall outside the category of leave regulated by EU law.

The LA provides for several different types of paid leave. It envisages leave days for important personal affairs. What qualifies as an important personal affair is illustrated by the LA with the examples of marriage, childbirth of a spouse, and the serious illness or death of a member of the immediate family. ${ }^{80}$ In addition, it grants leave for the purpose of workrelated education, ${ }^{81}$ and also envisages one free day for blood donors. ${ }^{82}$

The purpose of the aforementioned different types of paid leave is functionally distinct from that of paid annual leave. Their aim is to give the opportunity to deal with issues different from rest and leisure, such as dealing with certain important personal affairs, receiving education or for recovery from blood loss after donating blood. In our opinion, if circumstances granting the right to these different types of paid leave occur while a worker is taking or is supposed to be taking paid annual leave, the right to paid annual leave should not be affected. In the case of an overlap, the employer should be obliged to grant the worker a different period of annual leave or the untaken portion of annual leave. This conclusion can be bolstered by the provisions of Article 65(5) LA, which states that, for the purpose of accrual of the right to paid annual leave, the aforementioned types of paid annual leave are considered as time spent at work. In other words, they do not prevent paid annual leave from accruing. Given this, we see no reason why in the case of overlap they should consume days of paid annual leave. The Croatian Ministry of Labour ${ }^{83}$ has taken a similar view. If circumstances under which paid leave is to be granted occur during annual leave, the annual leave is interrupted. Spending annual leave on dealing with important personal matters (like the death of a family member) would be contrary to the purpose of annual leave. In such circumstances, the untaken annual leave should be exercised at a later date, after the period of unfitness to work has ended, in accordance

\footnotetext{
80 LA, art 65(1). The total duration of this leave is seven working days a year, unless otherwise stipulated by a collective agreement, employment by-laws or employment contract (LA, art 65(2)).

81 LA, art 65(4). The duration of this leave is determined by a collective agreement, an agreement between the works council and the employer or employment by-laws.

82 LA, art 65(6).

83 Opinion of the Ministry of Labour and Pension Systems, Klasa: 110-01/99-01/176, of 15 April 1999.
} 
with the arrangement made between the worker and his employer, and in compatibility with the interests of the undertaking.

The latter conclusion can be reached in relation to the overlap of already accrued paid annual leave and types of leave which are unpaid. Under Article 66 LA, the employer may grant a worker unpaid leave for unspecified reasons at his/her request. During such unpaid leave, the rights and obligations arising from employment or related to employment are suspended, unless otherwise specified by the law. Provisions on unpaid leave can be found in the Maternity and Parental Benefits Act (MPBA) ${ }^{84}$ Article 22 MPBA states that an employment relationship can be suspended after the exhaustion of maternity and parental leave until the child of the worker reaches the age of three. If the child of a worker has a severe disability, he/she can take unpaid leave until the child reaches the age of eight (Article 23 MPBA). Even though there is no jurisprudence on this matter, we think that the taking of these two types of leave cannot consume already accrued paid annual leave for two reasons. First, they would fall under the definition of 'non-working days established by law', which according to Article 56 LA are 'not calculated in the duration of annual leave', and second, they are unpaid. Given the fact that in both Croatian and EU law the entitlement to paid annual leave is formed of two constitutive elements, leave as the first one, and pay as the second, we think that it would be completely unacceptable from the point of view of both legal systems if unpaid leave could consume accrued paid annual leave. Therefore, in the case of overlap between accrued paid annual leave and unpaid leave from Article 66 LA and Articles 22 and 23 MPBA, any untaken paid annual leave should be scheduled in accordance with arrangements made between the worker and his employer, and in compatibility with the interests of the undertaking, at some later date. This does not mean, however, that a worker who is on unpaid leave for several years will be able to effectively use all the annual leave that has built up before a long period of unpaid leave. As we shall see in the next section, due to the provisions of the LA which regulate the carry-over period, the possibility for the exercise of non-taken annual leave can be quite limited.

However, before we end this section it is necessary to discuss one important difference between other paid leave and other unpaid leave regarding the accrual of paid annual leave. In the case of other paid leave, the LA is quite clear in that the right to paid annual leave continues to accrue while a worker is on such leave. On one hand, in the cases of Article 66 LA and Article 22 MPBA unpaid leave, both the LA and the MPBA state that during such leave, employment rights and obligations are sus-

${ }^{84}$ Zakon o rodiljnim i roditeljskim potporama (Maternity and Parental Benefits Act), Narodne novine (Official Gazette) 85/08, 110/08, 34/11, 54/13. 
pended. On the other hand, Article 23 MPBA is silent on the issue of the suspension of unemployment rights for working parents of children with severe disability. Despite this difference, in our opinion it seems that in all three of the aforementioned cases of unpaid leave the right to paid annual leave is prevented from accruing. ${ }^{85}$ If our presumption is true, it will be necessary for the CJEU to clarify whether this non-accrual of the right to paid annual leave is allowed from the perspective of EU law. In our opinion, in the case of Article 66 LA unpaid leave for unspecified reasons, there is no room for conflict due to the fact that the leave can be used for any reason, including rest and leisure. There is no obligation for the worker to give reasons for this leave. Moreover, the recognition of the accrual of the right to paid annual leave during this type of leave could serve as an incentive for employers to defer workers' requests for unpaid leave, as there is no obligation for the employer to grant Article 66 LA unpaid leave. This would undoubtedly render Article 66 LA unpaid leave meaningless. Furthermore, in our opinion, Article 66 LA unpaid leave can be comparable to the workers working 'zero-hours short time working' in the Heimann and Toltschin case mentioned in the previous section, where the CJEU said the non-accrual of paid annual leave during this work arrangement did not violate Article 7 WTD and the right to paid annual leave. The situation is a bit more controversial when it comes to the aforementioned unpaid leave envisaged by the MPBA. Unlike the situation in the Heimann and Toltschin case, workers taking this unpaid leave are not 'free to devote [themselves] to recreational and leisure activities', ${ }^{86}$ as they are taking care of their children. Therefore, the purpose of Articles 22 and 23 MPBA is different from that of paid annual leave. However, there are some important differences between Articles 22 and 23 MPBA on unpaid leave. In the case of Article 22 MPBA unpaid leave, workers do not enjoy health insurance and pension insurance rights, ${ }^{87}$ they have no right to salary and they receive no remuneration from the state. They can take Article 22 MPBA leave only once they have exhausted maternity and parental leave. In the case of Article 23 MPBA, workers still enjoy health insurance and pension rights as 'workers'. Even though they do not have the right to a salary from their employer, they receive remuneration from

\footnotetext{
85 According to Barjaktar, the right to paid annual leave accrues only during sick leave, maternity, parental and adoption leave. B Barjaktar, 'Uvjeti za prenošenje godišnjeg odmora u iduću kalendarsku godinu', published 5 June 2014 <http:/ / www.iusinfo.hr> accessed 28 June 2014. See Opinion of the Ministry of Labour and Pension Systems, Klasa: 110-01/1101/276, of 2 August 2011.

86 Heimann and Toltschin (n 30) para 29.

87 They can enjoy health insurance only as a member of the family of an insured person (Obligatory Health Insurance Act, art 10). They can enjoy pension insurance rights only if they pay the contributions for this insurance themselves (Pension Insurance Act 2013, art $18(2)(2))$.
} 
the state. ${ }^{88}$ In addition, they can exchange Article 23 MPBA unpaid leave for part-time work, which triggers the accrual of their right to paid annual leave. ${ }^{89}$ Finally, they can take Article 23 MPBA leave whilst being on parental leave, in which case their parental leave is suspended. ${ }^{90}$

The employment status of workers on Article 22 MPBA leave is comparable to the status of workers on Article 66 LA unpaid leave for unspecified reasons, but with the difference that an Article 22 MPBA request for leave cannot be refused by their employer. When we take into account that the purpose of this leave is different from that of paid annual leave, we are unsure if the aforementioned characteristics are strong enough to claim that the non-accrual of the right to paid annual leave during Article 22 MPBA unpaid leave is in violation of Article 7 WTD. ${ }^{91}$ However, due to the aforementioned characteristics of Article 23 MPBA unpaid leave, we think that the non-accrual of the right to paid annual leave would be in violation of Article 7 WTD. Moreover, we perceive Article 23 MPBA unpaid leave as a hybrid between parental leave and sick leave by virtue of its association with a child with a disability. In our opinion, the latter characteristic triggers the application of Directive $78 / 2000 / \mathrm{EC},{ }^{92}$ which specifically prohibits discrimination by association with regard to disability in employment and working conditions.

\section{Carrying unexercised annual leave over into the next calendar year}

\subsection{The EU law perspective}

The carry-over period is a mechanism which enables the exercise of paid annual leave in a period following the reference period for which it was aggregated. Its benefits lie in the fact that it allows the interests of workers and employers to be taken into account. On one hand, it serves as a safety valve in cases where a worker is precluded from taking annual leave in the reference period. ${ }^{93}$ It also takes account of the fact that

\footnotetext{
88 MPBA, art 23(7).

89 MPBA, art 23(2).

90 MPBA, art 23(1), and (3).

91 The answer would be probably a bit clearer if the CJEU ever answers the question of whether the right to paid annual leave accrues during parental leave. Since Article 22 MPBA unpaid leave comes on top of parental leave, a negative answer would probably imply that the non-accrual of paid annual leave during this leave does not violate Article 7 WTD. A positive answer, however, would still leave us in doubt.

92 Council Directive 2000/78/EC of 27 November 2000 establishing a general framework for equal treatment in employment and occupation [2000] OJ L303/16, arts 1, 3. Discrimination by association with disability within employment is prohibited in EU law. See Case C-303/06 Coleman [2008] ECR I-05603.

93 Karl Riesenhuber, 'Joined Cases C-350/06 and c-520/06, Gerhard Schultz-Hoff v
} 
the worker's need for rest does not increase linearly with the proportion of time spent working. On the other hand, it enables the employer to organise work effectively without losing time and money because his/her workers are on annual leave, ${ }^{94}$ protecting him/her from the risk that a worker will accumulate periods of absence of too great a length. ${ }^{95}$ From the perspective of the WTD, the issue of the carry-over period is closely related to the conditions for granting paid annual leave, which is in principle a matter for the Member States to decide. ${ }^{96}$ However, as we have seen in the previous section, when it comes to the conflict between paid annual leave and sick leave or maternity leave, the CJEU refuses to accept that the right to paid annual leave has lapsed and demands that the Member States enable it to be taken at a later date. In this way, the CJEU touched upon the issue of the carry-over period of untaken annual leave. Two types of questions emerged here. The first one concerned the possibility of the aggregation of several periods of annual leave, tackling in essence the issue of whether the WTD demands Member States recognise the carry-over period. The second addressed the length of that period.

The first case raising the issue of the aggregation of several periods of annual leave was Federatie Nederlandse Vakbeweging. ${ }^{97}$ The case concerned an information brochure published by the Dutch Ministry of Social Affairs and Employment stating that a worker can obtain cash in exchange for leave days above the mandatory minimum number of days per year or days which have been saved up over the course of previous years. Although the CJEU noted that the positive effect which that leave has for the safety and health of the worker is deployed fully if it is taken in the year prescribed for that purpose, namely the current year', ${ }^{98}$ it nonetheless recognised the inevitability of carrying annual leave over in some situations, stating that the significance of that rest period in that regard remains if it is taken during a later period'. ${ }^{99}$ This was due to the fact that, in the CJEU's view, leave may still, when taken during a later year, contribute to the safety and health of the worker. ${ }^{100}$ Therefore, "the possibility of financial compensation in respect of the minimum period of annual leave carried over would create an incentive, incompatible with the objectives of the directive, not to take leave or to encourage employees

Deutsche Rentenversicherung Bund and Mrs C. Stringer and Others v Her Majesty's Revenue and Customs, Judgment of the Court (Grand Chamber) of 20 January 2009, not yet reported [2009]' 46 CML Rev 2107, 2111. See also Schultz-Hoff and Stringer (n 23) para 42.

94 Reisenhuber (n 93).

95 Case C-214/10 KHS [2011] ECR I-11757, para 39.

96 Schultz-Hoff and Stringer (n 23) para 42.

97 Case C-124/05 Federatie Nederlandse Vakebeweiging [2006] ECR I-03423.

98 Federatie Nederlandse Vakebeweiging (n 97) para 30.

99 Federatie Nederlandse Vakebeweiging (n 97).

${ }^{100}$ Federatie Nederlandse Vakebeweiging (n 97) para 31. 
not to do so. ${ }^{101}$ By this, the CJEU recognised that the WTD right to paid annual leave implies in certain situations the right to carry over annual leave accumulated with time.

The cases which followed were more concerned with the duration of the carry-over period. The issue emerged for the first time as one of the potential and most criticised ramifications of the aforementioned SchultzHoff and Stringer case. To recap, one of the issues raised in this case, with regard to Mr Schultz-Hoff, was whether the entitlement to paid annual leave is extinguished at the end of the reference period of one calendar year and the carry-over period of 6 months $^{102}$ if a worker's sick leave has extended beyond the reference period and carry-over period. The Court gave its answer by stating that Article 7(1) WTD does not preclude, as a rule, national legislation which provides for the loss of the right to paid annual leave at the end of a reference or carry-over period. It added that the worker must have actually had the opportunity to exercise the right to paid annual leave for this rule to be applicable. ${ }^{103}$ Thus, the overall answer to the question posed by the national court was negative. Even though in the case of Mr Schultz-Hoff the carry-over period of the first 6 months of the following calendar year in hindsight seems short, the CJEU did not, however provide any guidance as to the duration of the carry-over period which would have been appropriate for providing the opportunity for annual leave in the case of its overlap with sick leave of a longer duration. Because of this omission, after the judgment in the Schultz-Hoff and Stringer case, the right to carry over untaken paid annual leave seemed almost unlimited.

Certain limits to the length of the carry-over period were set in the $K H S^{104}$ case. Mr Schulte suffered from a heart attack in January 2002, which left him seriously disabled until the end of his employment relationship in 2008. Since his incapacity to work prevented him from taking the right to paid annual leave, in 2009 he brought an action for payment of allowances in lieu of the untaken paid annual leave for the calendar years 2006, 2007 and 2008. The CJEU held that although the previous case law indicates that a national rule laying down a carry-over period cannot stipulate that a worker's right to paid annual leave will lapse without him actually having had the opportunity to exercise that right, 'that conclusion must none the less be qualified in specific circumstances such as those in the main proceedings'. ${ }^{105}$ Otherwise, a worker unfit for

\footnotetext{
${ }^{101}$ Federatie Nederlandse Vakebeweiging (n 97) para 32.

102 The provisions of national law which were relevant to the Schultz-Hoff case can be found in Schultz-Hoff and Stringer (n 23) Opinion of AG Trstenjak, para 6.

${ }^{103}$ Schultz-Hoff and Stringer (n 23) para 43.

${ }^{104}$ KHS (n 95).

${ }^{105}$ KHS (n 95) para 28.
} 
work for several consecutive years would be entitled to accumulate annual leave without any limit. The right to such unlimited accumulation of entitlements to paid annual leave, acquired during such a period of unfitness for work, 'would no longer reflect the actual purpose of the right to paid annual leave'. ${ }^{106}$ The Court then provided guidance as to the duration of the carry-over period which would be appropriate to uphold the right to paid annual leave. It stated that the carry-over period must take into account the specific circumstances of a worker who is unfit for work for several consecutive reference periods. Besides this, any carryover period must ensure that the worker can have, if needed, rest periods that may be staggered, planned in advance and available in the longer term, and that it must also be substantially longer than the reference period in respect of which it is granted. ${ }^{107}$ Since the carry-over period of 15 months envisaged by national law was longer than the reference period of one calendar year to which it related, the CJEU concluded that the purpose of Article 7(1) WTD was safeguarded. ${ }^{108}$ Following this line of reasoning, in the Neidel case ${ }^{109}$ the CJEU ruled that the carry-over period of 9 months, as it was shorter than the reference period of one year to which it related, did not meet the requirements of the WTD. ${ }^{110}$

\subsection{The Croatian law perspective}

In section 2 , it was mentioned that the LA provides for four weeks of paid annual leave per reference period of one calendar year. ${ }^{111}$ In this section, we will introduce the rules on the organisation of paid annual leave which are relevant to the discussion on the carry-over period. They will then be analysed against the backdrop of CJEU case law.

In principle, the planning of annual leave is in the hands of the employer, who has to publish a schedule of the paid annual leave for the current year by 30 June of the same year. ${ }^{112}$ Rules on the establishment of this schedule balance the interests of workers and the employer in the following way. Every worker is allowed to use one day of paid annual leave when it pleases him/her. ${ }^{113}$ The employer must respect the requested dates for annual leave of part-time workers who are employed by different employers, unless all employers of that part-time worker reach

\footnotetext{
106 KHS (n 95) para 30.

107 KHS (n 95) para 38.

108 KHS (n 95) para 43.

109 Case C-337/10 Neidel [2012] ECR I-000.

110 Neidel (n 109) paras 41-42.

111 LA, art 55(1).

112 LA, art 64(1).

${ }^{113}$ LA, art 64(5).
} 
agreement on the dates of the worker's annual leave. ${ }^{114}$ In all other situations, an employer is only obliged to take into account the interests of the workers and balance them with the needs of the work process. ${ }^{115}$

Unless agreed differently, the LA stipulates that a worker can take his/her leave in two parts. Two consecutive weeks of paid annual leave have to be taken in the reference period, ${ }^{116}$ and the untaken remainder of the annual leave has to be used by 30 June of the following calendar year. ${ }^{117}$ However, if the worker is given the opportunity to use the whole of their paid annual leave within the reference period, he/she has no right to carry it over. ${ }^{118} \mathrm{~A}$ special exemption to the rule that full annual leave cannot be carried over into the following calendar year has been given to two groups of workers. The first one consists of workers who have not been able to take their paid annual leave within the reference period due to illness, or maternity, parental or adoption leave. This category of workers can use any untaken paid annual leave by 30 June of the following calendar year. ${ }^{119}$ Even more preferential treatment has been given to a second category of workers. Members of a ship's crew, posted workers and workers who have performed civil defence duty are entitled to carry over untaken annual leave until the end of the following calendar year. ${ }^{120}$ It is also important to state that in all cases carried-over paid annual leave has to be used by the end of the envisaged period. ${ }^{121}$

The aforementioned rules demonstrate the following. First, the LA recognises a vast category of 'ordinary workers' that encompasses all workers who do not fall within one of the two aforementioned privileged categories. They can use the carry-over period only if their employer did not give them an opportunity to use their full paid annual leave within the reference period. Second, the first 6 months of the following calendar year is a general rule on the duration of the carry-over period, which is as applicable to workers who have been on sick, maternity, parental or adoption leave as it is to 'ordinary workers'. However, in comparison with 'ordinary workers', the former category of workers is in a better position, because they can use the whole of their paid annual leave in the first six months of the following year. Third, the most privileged category of

\footnotetext{
${ }^{114}$ LA, art 64(2).

${ }^{115}$ LA, art 64(3).

${ }^{116}$ LA, art 62(2).

${ }^{117}$ LA, art 63(1).

${ }^{118}$ LA, art 63(2).

${ }^{119}$ LA, art 63(3).

${ }^{120} \mathrm{LA}$, art 63(4).

${ }^{121}$ Opinion of the Ministry of Labour and Pension Systems, KLASA: 110-01/10-01/24, URBROJ: 526-08-01-01/1-10-2, of 23 February 2010 and KLASA: 110-01/12-01/161, URBROJ: 524-08-01-01/5-12-2, of 12 April 2012 <http://www.mrms.hr/topics/zakon-o$\mathrm{radu} / \mathrm{page} / 20 />$ accessed 28 June 2014.
} 
workers are the members of a ship's crew, posted workers and workers who have performed civil defence duty, as they benefit from a carry-over period of one year.

With the benefit of the hindsight of CJEU case law, we find that all of the aforementioned rules on the carry-over period raise doubts as to their compatibility with EU law. The discrepancy between national and EU law is most striking when it comes to workers on sick, maternity, parental and adoption leave.

As far as sick leave is concerned, in Schultz-Hoff and Stringer and Neidel, the CJEU ruled that the carry-over periods of 6 months and 9 months respectively were not long enough to accommodate the right to paid annual leave with sick leave, because they were shorter than the reference period of one calendar year that they referred to. Given the fact that in Croatian law this type of leave can last for more than a year, ${ }^{122}$ it is clear that the carry-over period of 6 months is not long enough to accommodate long-term sick leave.

Turning to maternity, parental and adoption leave, it is important to state that the CJEU has so far not examined the actual duration of the national regulation concerning the carry-over period in cases of overlap with paid annual leave. However, we find that the Schultz-Hoff/ Neidel line of jurisprudence could be of equal importance here. Namely, the purpose of paid annual leave is seriously hampered by the duration of the carryover period applicable to this category of workers, given that in Croatian law maternity leave and adoption leave can last up to 6 months, ${ }^{123}$ and parental leave can last between 6 and 30 months. ${ }^{124}$ The discrepancy is, of course, even more striking when we take into account maternity and parental leave, and adoption and parental leave as aggregated periods of time. Thus, in our opinion, a 6-month period is too short to guarantee the appropriate accommodation of the annual leave of workers on maternity, parental or adoption leave, especially when we take into account that their employer at the same time has to keep in mind the organisation of the work process and plan the annual leave of other workers. Besides this, maternity and parental leave on the grounds of the birth or adoption of a child are periods of leave recognised by EU law. ${ }^{125}$ The taking of

\footnotetext{
${ }^{122}$ Zakon o obveznom zdravstvenom osiguranju (Obligatory Health Insurance Act), Narodne novine (Official Gazette) 80/13, 137/13, arts 48(2), 52(1).

${ }^{123}$ MPBA, arts 12(1) (maternity leave), 36(1) (adoption leave).

${ }^{124}$ MPBA, arts 14 (parental leave), 36(3) (parental leave for adoptive parents).

125 Directive 92/85/EEC (n 53) (maternity leave). Council Directive 2010/18/EU of 8 March 2010 implementing the revised Framework Agreement on parental leave concluded by BUSINESSEUROPE, UEAPME, CEEP and ETUC and repealing Directive 96/34/EC (Text with EEA relevance) [2010] OJ L68/13 (parental leave on the grounds of birth or adoption of a child).
} 
one of these periods of leave to the detriment of paid annual leave would be, in itself, contrary to EU law. ${ }^{126}$ However, a carry-over period of longer duration would by no means provide the employer with the necessary flexibility and safeguard the workers' right to paid annual leave.

A similar line of argument can be used with regard to workers who fall into the category of 'ordinary workers' who also benefit from the 6-month carry-over period. As has been demonstrated in section 3, Croatian law recognises different types of paid and unpaid leave which are not recognised by EU law and which have not been discussed by the CJEU. Workers wishing to carry over their annual leave fall under the category of 'ordinary workers' who can carry only two weeks of annual leave forward to the next year and who are in that respect in an even worse position than workers on sick, maternity, parental or adoption leave. If the presumption made in section 3 is true that paid annual leave has to be accommodated with other types of paid and unpaid leave unrecognised by EU law but known to Croatian law, we find that the carry-over period of 6 months is not long enough to enable the effective realisation of the paid annual leave. In addition, in the case of the overlap of paid annual leave and other types of paid and unpaid leave known to Croatian law, we find that 'ordinary workers' must also be in a position to take full paid annual leave in the carry-over period.

Finally, we raise doubts as to the duration of the carry-over period of the most privileged group of workers: members of a ship's crew, posted workers and workers who have performed civil defence duty, who can take their full paid annual leave in the following year. If we follow the same line of argument as the Court used in KHS and Neidel, we find the one-year carry-over period to be still too short to safeguard the right to paid annual leave in the case of its overlap with any other type of leave, since in the aforementioned cases the CJEU demanded the carry-over period be substantially longer than the reference period of one calendar year.

\section{Concluding remarks}

In this article, we have examined three aspects of Croatian legislation regarding paid annual leave which raise doubts concerning the proper implementation of Article 7 WTD. In these concluding remarks, we shall introduce our suggestions on how to bring Croatian law into conformity with EU law.

In section 2 , we examined the regulation on minimum periods of employment as a precondition for the entitlement to paid annual leave. We

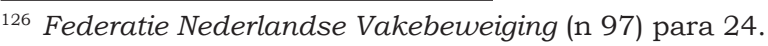


showed how Article 59(2) LA, according to which 'at least one half of a month of work is rounded up to a whole month [of work]', leads to the exclusion of any work shorter than half a month from the calculation of paid annual leave. We also demonstrated that this exclusionary effect of Article 59(2) LA cannot be justified from the position of the relevant CJEU case law. As Article 7 WTD has direct effect, in vertical situations it will be necessary to set aside this national provision to give full effect to Article 7 WTD. In horizontal situations, this discrepancy between national law and EU law can be resolved at the level of interpretation of the overall rules on the calculation of proportional time. Namely, the rule in Article 59(2) LA can be interpreted in a way that less than half a month of work is rounded up to a half a month of work. In this way, keeping in mind the mathematical formula for the calculation of the proportional time of paid annual leave $(X / 12 \times(W D P W \times 4)=$ Rounded days of paid annual leave), workers who work less than a half of a month on the basis of 3 to 5 days a week will have one day of paid annual leave. ${ }^{127}$ Workers who work less than 3 days a week would have half a day of paid annual leave. ${ }^{128}$ In our opinion, this interpretation of Article 59(2) LA would be in conformity with Article 7 WTD and would not go against national rules on the calculation of the proportional time of paid annual leave.

Section 3 was devoted to the relationship between paid annual leave and other periods of leave with regard to its first two strands, i.e. the question of whether the right to paid annual leave accrues during other periods of leave, and the issue of whether other periods of leave consume accrued but untaken paid annual leave. Regarding maternity, parental, adoption and sick leave, we have demonstrated that national legislation does not pose any particular problem from the standpoint of EU law. These types of leave are not calculated in annual leave, and annual leave does not stop accruing during these types of leave. The same conclusion has been reached with regard to paid leave for the important personal reasons, work-related education, and one free day for blood donors envisaged by the LA. In addition, already accrued paid annual leave cannot be consumed either by the unpaid leave for unspecified purposes mentioned in Article 66 LA or by the unpaid leave for the purposes of child care envisaged by Articles 22 and 23 MPBA. However, during these three types of leave, we are of the opinion that paid annual leave does not accrue under national law. Acknowledging that the ultimate say should be left to

\footnotetext{
127 To recall, this is because Article 59(2) LA states that at least half of a day of annual leave is rounded up to a whole day of leave. The calculation on the basis of 3 days of work per week is: $0.5 / 12 \times 3 \times 4=0.5$. The calculation on the basis of 5 days of work per week is: $0.5 / 12 \times 5 \times 4=0.83$. Both calculations give 1 day of paid annual leave.

128 The calculation on the basis of 2 days of work per week is: $0.5 / 12 \times 2 \times 4=0.33$, which is less than half a day of annual leave. Therefore, this worker would have half a day of paid annual leave.
} 
the CJEU on whether this non-accrual of the right to paid annual leave is in accordance with EU law, we believe the following: the non-accrual of paid annual leave during Article 66 LA unpaid leave for unspecified purposes is not in conflict with Article 7 WTD, because this leave can be used for rest and pleasure and is thus comparable to 'zero-hours short time working' in Heimann and Toltschin. However, we raise doubts as to whether the non-accrual of paid annual leave during Article 22 and Article 23 MPBA unpaid leave represents the proper application of Article 7 WTD, since the purpose cannot be comparable to the purpose of paid annual leave.

Finally, in section 4 we analysed national provisions on the carryover period, examining the issue of its existence and length. We concluded that the LA recognises three categories of workers. 'Ordinary workers' who fall into the first category can only carry over two weeks of paid annual leave, which have to be used by 30 June of the following year. The second category encompasses workers on sick, maternity, parental or adoption leave, who can use all untaken paid annual leave until the aforementioned date. The most privileged category are members of a ship's crew, posted workers and workers who have performed civil defence duty, who can carry over all untaken paid annual leave until 31 December of the following year. We concluded that the length of the carry-over period is disputable from the position of EU law with regard to all three categories when paid annual leave has been interrupted by other periods of leave. Since the CJEU's interpretation that the carry-over period in the case of sick leave has to be substantially longer than the reference period (which in Croatian law amounts to one calendar year), neither a six-month nor a one-year carry-over period is long enough to accommodate the untaken paid annual leave. Thus, with regard to sick leave, in vertical situations the national judge should set aside the conflicting provisions of the LA and determine a longer duration of the carry-over period, which in our opinion, due to the judgment in KHS, does not have to go over 15 months following the year for which it was accrued. In horizontal situations, we hold that a conforming interpretation is not possible due to the preciseness of national legislation. Namely, we find it difficult to see how the stipulations of 'until 30 June / 31 December of the following year' can be interpreted in any other way than what they state. In horizontal situations, however, workers on sick leave have the option of claiming damages from the State for the improper implementation of Article 7 WTD. Turning to periods of leave other than sick leave, it is important to state that the CJEU has not had the opportunity to express itself regarding national provisions on the exact length of the carry-over period of maternity, parental, adoption or any other leave. Therefore, we think that national judges should primarily seek the answer from the CJEU through the mechanism of the preliminary reference procedure. In our opinion, a 
six-month period is not long enough to accommodate maternity, parental or adoption leave and we see no reason why the CJEU would not in this matter follow its line of reasoning developed with regard to sick leave in Neidel and KHS. We reach the same conclusion with regard to the carryover period of paid annual leave in the case of overlap with all paid and unpaid leave envisaged by the LA and MPBA. This equally applies to the one-year carry-over for workers who are members of a ship's crew, posted workers or workers who have performed civil defence duty, as it is not substantially longer than the one-year reference period it refers to. 
